\title{
Ocular albinism with late-onset sensorineural deafness
}

INSERM

\section{Source}

INSERM. (1999). Orphanet: an online rare disease and orphan drug data base. Ocular albinism with late-onset sensorineural deafness. ORPHA:1000

Ocular albinism with late-onset sensorineural deafness is a rare, $\mathrm{X}$-linked inherited subtype of ocular albinism characterized by severe visual impairment, translucent paleblue irises, a reduction in the retinal pigment and moderately severe deafness with onset ranging from adolescence to fourth or fifth decade of life. 